\title{
Sesquiterpene and Ecdysteroid from Achyranthes aspera L.
}

\author{
G/meskel G/micael ${ }^{1^{*}} \quad$ Ashebir Fiseha ${ }^{2}$ \\ 1.Traditional and modern medicine directorate, Ethiopian Public Health Institute, Addis Ababa,Ethiopia \\ 2.Department of Chemistry, Addis Ababa University, PO Box 30270, Addis Ababa, Ethiopia
}

\begin{abstract}
Background:- Achyranthes aspera L. (Amaranthaceae) locally known as "Telenge or ambulale" (Amharic) and Muchele (Tigrigna)" is one of the traditional medicinal plant used as contraceptive, for relieving asthma and cough, and anti snake bite in the indigenous health care delivery system of Ethiopia Objective:- Identifying and characterization of the chemical constituents of elucidations of the n-buthanol fractions of the methanolic leaves extracts of Achyranthes aspera Method:- Structural elucidations of the compounds was based on IR, UV, ${ }^{1} \mathrm{D}$ NMR $\left({ }^{1} \mathrm{H},{ }^{13} \mathrm{C} \& \mathrm{DEPT}\right)$ and ${ }^{2} \mathrm{D}$ NMR (COSY, HMQC \&HMBC) spectroscopic techniques.Result: Phytochemical investigation of the leaves of this plant resulted in the isolation and characterization of two compounds AA-1and AA-2. Compound AA-1 is sesquiterpene named as 4,4a,7,8-tetrahydro-4-hydroxy-4a,7,8-trimethyl-8-(tetrahydro3,4,5-trihydroxy-6-(hydroxymethyl)-2H-pyran-2-yloxy) naphthalen-2(3H)-one. Compound AA-2 is an insect molting ecdysteroid hormone named as, 20-hydroxyecdysone. Conclusion: From this study, two compounds were isolated and structurally identified. Compound AA-1 is the first report from $A$. aspera and plants belonging to the same species and family. While compound AA-2 was reported previously from the same plant.
\end{abstract}

Keywords: Achyrannthes aspera, sesquiterpene, ecdysteroid, structural elucidation

DOI: $10.7176 / \mathrm{CER} / 11-3-02$

Publication date: April $30^{\text {th }} 2019$

\section{Introduction}

Plants are used medicinally in different countries and are a source of many potent and powerful drugs (Periyasamy and Mahalingam, 2010). Medicinal plants have multipurpose uses such as for pharmaceutical purpose, preparing foodstuffs, insecticides, antioxidants, coloring matters, flavors and fragrances, extraction of enzymes, pheromones, etc (Theoneste, 2002). The genus Achyranthes belongs to the family Amaranthaceae. It is perennial stiff erect herb, growing up to $1 \mathrm{~m}$ height distributed as weed up to an altitude of $2000 \mathrm{~m}$ in many regions of Ethiopia. Some of the species of belonging to the genus Achyranthes viz. A. fauriei, A. bidentata, A. japonica, A. ferruginea have been investigated for their constituents and screened for pharmacological activity (Shendkar, 2011). Achyranthes aspera L., locally known as "Telenge or ambulale" is one of the traditionally used anti-fertility plants in the indigenous health care delivery system of Ethiopia (Workineh, et al., 2006).

The plant is highly esteemed by traditional healers and used for the treatment of asthma, bleeding, boils, bronchitis, cold, cough, colic, debility, dropsy, dog bite, dysentery, ear complications, headache, leucoderma, pneumonia, renal complications, scorpion bite, snake bite, skin diseases and in facilitating delivery (Abdul and Athar, 2008., Singh, 2010).

Chemical investigations of the different parts of Achyranthes aspera resulted in the isolation \& identification Alkaloids, flavonoids, saponins, steroids and terpenoids from the leaves of the plant (Saurabh and Khosa, 2011). A. aspera is one of the important medicinal plants having many therapeutic uses as Odontalgic, Rheumatism, Bronchitis, skin disease, as an anti-asthmatic and for insect bite (Tullanithi, 2011, Amrutia, 2011). The chloroform and ethanol extracts of roots of the Achyranthes aspera are reported to have anti-implantation \& abortifacient activity. The ethanol extract of the root posses spermicidal activity. The aqueous and methanolic extracts of the whole plant have hypoglycemic effect (Shendkar, et al., 2012 and Pradip et al., 2012). Previous investigation of the leaves of Achyranthes aspera revealed the presence of steriodal and triterenoidal saponins and flavonoid glycosides (Kunert et al., 2000 and Michl et al 2000 ). In the current study we report the isolation and characterization of sesquiterpene and ecdysteroid, from the leaves of Achyranthes aspera using different spectroscopic techniques.

\section{Materials and Methods}

\subsection{General}

${ }^{1} \mathrm{H},{ }^{13} \mathrm{C}$ and ${ }^{2} \mathrm{D}$-NMR spectra were recorded with Bruker advance $400 \mathrm{MHz}$ spectrometer with using $\mathrm{CD}_{3} \mathrm{OD}$ and TMS as internal started. The ultraviolet and visible (UV-Vis) spectra were taken on GENESY'S 2PC UV-Vis scanning spectrometer in the range $200-1000 \mathrm{Cm}^{-1}$ Infrared (IR) spectra were obtained on Perkin-Elmer BX Infrared spectrometer using $\mathrm{KBr}$ and $\mathrm{MeOH}$ in the range $4000-400 \mathrm{Cm}^{-1}$. Solvents were removed using the Buchi type rota vapor under reduced pressure at $30^{\circ} \mathrm{C}$. Mixtures of compounds were separated using chromatoron (model 79247), Column Chromatography and Preparatory TLC. TLC analyses were carried out on TLC plates $0.2 \mathrm{~mm}$ thick layer of Merck silica gel $60 \mathrm{~F}_{254}$ coated on aluminum foil. Compounds on TLC were detected using UV light on the wave length of 254 and $365 \mathrm{~nm}$ and spraying with $1 \%$ vanillin in sulfuric acid. 


\subsection{Plant material}

The fresh leaves and stem containing the fruits of the plant were collected from Mekelle, capital City of Tigray regional state of Ethiopia, which is $780 \mathrm{~km}$ from Addis Ababa, and identified by the botanist national herbarium of Ethiopia. The leaves and the stems were collected separately and the collected leaves are dried at room temperature.

\subsection{Method of extraction and isolation}

Air dried and finely powdered leaves of the plant $(500 \mathrm{~g})$ were defatted with petroleum ether in a percolator at room temperature for $72 \mathrm{~h}$. After the extract was filtered, the solvent free powder(the marc) was exhaustively extracted with methanol in a percolator and the solvent was removed using Rota evaporator to afford a greenish gum (45 g). The crude methanol extract was then taken up in water and re-extracted with diethyl ether until all the chlorophyll pigments were removed. The aqueous phase was then partitioned with n-butanol saturated with water $(300 \mathrm{ml})$ three times. The n-butanol partitioned was concentrated under reduced pressure using vacuum distillation to give crude mixture $(3 \mathrm{~g})$. This mixture was dissolved in the solvent system of $\mathrm{MeOH} / \mathrm{CHCl}_{3}(8: 2)$ and subjected to Chromatotron and 30 fractions each $20 \mathrm{ml}$ were collected using $100 \mathrm{ml}$ Erlenmeyer flask by monitoring the TLC of the eluants using $\mathrm{CHCl}_{3} / \mathrm{MeOH} / \mathrm{EtOAc}(6: 2: 2)$ as solvent system to identify the components of the fractions collected. The first seventeen fractions (i.e F1-F17) were collected using $\mathrm{MeOH} / \mathrm{CHCl3}$ (8:2) as solvent system. TLC was checked fractions that had similar retention factor (RF) were combined together. Based on this F4, F5 and F6 were mixed and the solvent was removed using rotavapor. The combined fractions are also subjected to Column chromatography (CC) on silica gel (20g) to afford 12 fractions collecting in a test tube. Fraction 6 was subjected to Preparatory Thin Layer Chromatography (PTLC) to give compounds AA-1.

Compound AA-1 is yellowish semisolid with RF value 0.38. It is UV active and showed a purple color seeing in UV lamp at $254 \mathrm{~nm}$. After spraying with $1 \%$ vanillin in $\mathrm{H}_{2} \mathrm{SO}_{4}$ and heated in hotplate a purple color was observed. Repeated column chromatography on silica gel (solvent system, $\mathrm{CHCl} 3 / \mathrm{MeOH}(8: 2)$ ) of fourteenth fraction collected above afforded $11 \mathrm{mg}$ of compound AA-2. It gives a yellow color spot on TLC after spraying with $1 \%$ vanillin in $\mathrm{H}_{2} \mathrm{SO}_{4}$ with $\mathrm{RF}$ value of 0.44 . It is less polar compared to compound AA-1.

\section{Result}

Phytochemical investigation of the leaves of this plant resulted in the isolation and characterization of two compounds AA-1 and AA-2. Compound AA-1 is sesquiterpene named as 4,4a,7,8-tetrahydro-4-hydroxy-4a,7,8trimethyl-8-(tetrahydro-3,4,5-trihydroxy-6-(hydroxymethyl)-2H-pyran-2-yloxy) naphthalen-2(3H)-one. Compound AA-2 is an insect molting ecdysteroid hormone named as, 20-hydroxyecdysone. Compound AA-1 is the first report from $A$. aspera and plants belonging to the same species and family. While compound AA-2 was reported previously from the same plant.

\section{Discussion}

Compound AA-1 was isolated as a yellowish semi solid crystal/ amorphous powder, with RF value 0.38 in $\mathrm{CHCl}_{3} / \mathrm{MeOH} /$ EtOAc (6:2:2). In the IR spectrum strong and sharp absorption band at $3411 \mathrm{~cm}^{-1}$ indicated the presence of $\mathrm{OH}$ group. An absorption band at $1654 \mathrm{~cm}^{-1}$ indicated the $\mathrm{C}=\mathrm{O}$ stretch of $\alpha$, $\beta$-unsaturated carbonyl group. The UV spectrum absorption band at $\lambda \max 236 \mathrm{~nm}$ (in $\mathrm{MeOH}$ ) shows the presence of $\alpha$, $\beta$-unsaturated carbonyl chromophore.

${ }^{1} \mathrm{H}$ NMR spectrum analysis of the compound AA-1 showed $1 \mathrm{H}$ doublet at $\delta 6.01$ indicating a methine attached to carbon 9 and $1 \mathrm{H}$ singlet at $\delta 5.89$ indicating a methine attached to the olefenic carbon 4 . On the other hand, $1 \mathrm{H}$ a doublet of doublet at $\delta 5.75$ indicating a methine attached to the olefenic carbon 8 . A $1 \mathrm{H}$ triplet at $\delta 4.55$ indicating the presence of methine attached to oxygen and sharp singlet peak at $\delta 3.32$ indicating the presence of OH group. The spectrum also indicated two $3 \mathrm{H}$ singlet at $\delta 1.96$ and 1.03 indicating the presence of two methyl group attached to quaternary carbons. A $3 \mathrm{H}$ doublet at $\delta 1.29$ showed the presence of methyl group attached to methine (Table 1).

Comparison of the ${ }^{13} \mathrm{C}$ with DEPT-135 NMR spectra revealed a quaternary carbon atom at $\delta 199.85$, which indicated the presence of conjugated carbonyl group. The quaternary carbon peak at $\delta 165.70$ showed an olefenic carbon $\beta$ to the carbonyl group. The peaks at $\delta 132.36,132.30$ and 125.72 indicated the existence of three olefinic carbon atoms. In addition, two quaternary carbon atoms in the aliphatic regions were also observed at $\delta 78.61$ and 41.03. DEPT 135 NMR displayed two peaks at $\delta 61.43$ and 49.35 that showed the presence of two methylene groups, in which the down field shifted peak at $\delta 61.43$ is oxygenated carbon The nine peaks left were assigned to six methine at $\delta 76.96,76.80,73.55,73.23,70.28$ and 22.0)-which are attached to oxygen and three methyl groups at $\delta 23.30,20.8$ and 18.16). The ${ }^{1} \mathrm{H},{ }^{13} \mathrm{C}$ and DEPT NMR data of the compound is summarized in Table 1.

The ${ }^{2}$ D NMR (COSY, HMQC and HMBC) spectra of the compound AA-1 also further supported in predicting the structure. From COSY spectrum (Table 2) the proton peak at $\delta 6.01(\mathrm{H}-9)$ is correlated with the proton peak at $\delta 5.75(\mathrm{H}-8)$. The spectrum also shows that the proton peak at $\delta 1.96(\mathrm{H}-12)$ is correlated with the proton peak at $\delta 1.29(\mathrm{H}-13), 1.05(\mathrm{H}-7)$ and $5.89(\mathrm{H}-4)$. 
From HMQC spectrum (Table 3), the protons at $\delta 6.01(1 \mathrm{H}, \mathrm{d})$ and $5.75(1 \mathrm{H}, \mathrm{dd})$ correlated with the carbon peaks at $\delta 132.36$ and 132.30 respectively. And the proton peak at $\delta 4.55(1 \mathrm{H}, \mathrm{t})$ correlated with the carbon peak at $\delta$ 73.2. The HMBC spectrum (Table 4) also shows the proton on C-2 has long range correlation with C-3, C-4, C-6 and C-10 as shown in Figure 1. On the other hand, the proton on C-9 correlates with C-1, C-5, C-6 and the proton on C-8 also correlates with C-13, C-6 and C-1 as shown in Figure 2.

Based on the spectroscopic data, the proposed structure of compound AA-1 is indicated in Figure 3. (4,4a, 7, 8-tetrahydro-4-hydroxy-4a, 7, 8-trimethyl-8-(tetrahydro-3, 4, and 5-trihydroxy-6 (hydroxymethyl)-2H-pyran-2 yloxy) naphthalen-2(3H)-one). The isolation and characterization of this compound is the first report from $A$. aspera and plants belonging to the same species and family.

Compound AA-2 is previously reported in the same plant was also isolated as a yellowish amorphous solid with $\mathrm{RF}$ value of 0.44 in $\mathrm{CHCl}_{3} / \mathrm{MeOH} / \operatorname{EtOAc}$ (6: 2: 2). In the IR spectrum absorption band at $3350 \mathrm{~cm}^{-1}$ indicated the presence of hydroxyl group. An absorption band at $1450 \mathrm{~cm}^{-1}$ indicated the $\mathrm{C}=\mathrm{O}$ stretch of $\alpha$, $\beta$ unsaturated carbonyl group. The ${ }^{1} \mathrm{H}$ NMR spectrum of compound AA-2 shows that $1 \mathrm{H}$ doublet at $\delta 5.83$ indicates the methine attached to the $\mathrm{C}-7$ and $1 \mathrm{H}$ triplet at $\delta 3.17$ indicates methine attached to $\mathrm{C}-9$. A sharp singlet peak at $\delta 4.6$ indicates the presence of $\mathrm{OH}$ group. The ${ }^{1} \mathrm{H}$ NMR spectrum also shows that there are five $3 \mathrm{H}$ singlet peak at $\delta 1.30,1.22,1.21,0.95$ and 0.90 which indicated that the presence of five methyl groups attached to the quaternary carbons. ${ }^{13} \mathrm{C}$ NMR spectrum showed that compound AA-2 has 27 carbon atoms. The peak at $\delta 206.5$ indicates that the presence of ketone carbonyl group. The ${ }^{13} \mathrm{C}$ NMR also revealed the presence of two olefenic carbons at $\delta 168$ and 122.1. DEPT-135 spectra indicates that there are seven quaternary carbon, seven methine, eight down ward methtylene groups at $(\delta 42.4,37.3,35.1,32.5,31.8,30.8,27.3,23.7)$ and five quaternary methyl carbons, from these carbon groups six are resonated in the region corresponding to oxygenated carbons $(\delta 85.2,78.4,77.9,71.3$, 68.7, and 68.5) Table 5.

The above spectral data were further supported by ${ }^{2} \mathrm{D}$ NMR data (COSY, HMQC and HMBC). From COSY spectrum of compound AA-2 (Table 6), the proton peak at $\delta 5.83$ correlated with the proton peak at $\delta$ (3.17 and 1.79). The spectrum also shows that the proton peak at $\delta 2.41$ correlated with the proton peak at $\delta 2.08$. From HMQC spectrum (Table 7), the proton peak at $\delta 5.83(1 \mathrm{H}, \mathrm{s})$ is correlated with carbon peak at $\delta 122.1$ and the proton peak at $\delta 3.17(1 \mathrm{H}, \mathrm{t})$ correlated with the carbon peaks at $\delta 35.1$. The proton peak at $\delta 0.95(3 \mathrm{H}, \mathrm{t})$ and 0.90 $(3 \mathrm{H}, \mathrm{t})$ correlated with the carbon peak at $\delta 24.4$ and 18.0 respectively. HMBC spectrum of compound AA-2 (Table 8) also shows correlation of some proton with the carbons. The carbon -proton correlation is shown in Figure 4.

Based on the spectroscopic data obtained and in comparison with literature (Kunert et al., 2000), the structure of compound AA-2 is proposed to be as 20-hydroxyecdysone (Figure 5).

\section{Conclusion}

In present study, two polar compounds were isolated and characterized from the leaves of A. aspera. Compound AA-1 is the first report from $A$. aspera and plants belonging to the same species and family. While compound AA2 was reported previously from the same plant. It is highly recommended that further studies were required to assess the pharmacological effect of the new compounds reported from this plant.

\section{Acknowledgement}

G.G gratefully acknowledges School of graduate studies, Addis Ababa University for sponsorship and financial support to undertake the research. Ato Yadesa Melaku is appreciated for generating NMR data.

\section{Conflict of Interests}

The authors declare that there is no conflict of interests regarding the publication of this paper

\section{References}

Abdul V. K., and Athar A. k.; Ethno medicinal uses of Achyranthes aspera (Amaranthaceae) in management of gyna ecological disorders in western Uttar Pradesh, India. Journal of Pharmacy and practice, 2011, 1(1): 1$3(7)$

Kunert, O., Haslinger, E., Schmid, M.G., Reiner J., Bucar, F., Mulatu, E., Abebe, D. and Debella, A. Monatshefte fur Chemie, 2000, 131, 195-204

Michl, G., Abebe, D., Bucar, F., Debella, A., Kunert, O., Schmid, M.G., Mulatu, E., and Haslinger, E. Helvetica Chemica Acta, 2000, 83, 359-363

Periyasamy A., and Mahalingam k. Phytochemical screening and antimicrobial activity from five Indian medicinal plants against human pathogens. Middle-east ournal of scientific resaearch, 2010, 5(3): 157-162 (1)

Pradip K.M., Jain S.K., Nand L., and Shashi A.; A review on antiulcer activity. International Journal of pharmaceutical sciences and research, 2012, 2487- 2493(13)

Saurabh S., and Khosa R. L.; Achyranthes aspera-An important medicinal plant. J. Nat. Prod. Plant Resour, 
2011, 1 (1): 1-14(9)

Shendkar C. D., Chandrachood P. S., Pawar A. B., Lavate S. M., and Deshpande N. R.; Quantitative estimation of macro, micro nutrients and trace elements by X-ray fluorescence spectroscopy (XRF) from Achyranthes aspera Linn. International Journal of ChemTech Research, 2011, 3(2): 610-613(5)

Singh V. K., Ali Z. A., and Zaidi S.; Ethno medicinal uses of plants from Gonda district forests of Uttar Pradesh. India Fitoterapia LXVII, 2010, 2: 129-39(8)

Theoneste M.; The extraction, purification and evaluation of compounds from the leaves of Leonotis leonorus for anticonvulsant activity. Journal of Applied Pharmaceutical Science, 2002, 1 (8): 112-1117(2

Tullanithi K.M., Sharmila B. and Gnanendra T.S.; Preliminary Phytochemical analysis and Antimicrobial activity of Achyranthes aspera Linn. International Journal of Biological Technology, 2010, 1(3):35-38(10)

Workineh S., Eyasu M., Legesse Z., and Asfaw D.; Effect of Achyranthes aspera L. On fetal abortion, uterine and pituitary weights, serum lipids and hormones. African Health Sciences, 2006, 6(2):108-112(6)

\section{Abbreviation and Acronyms}

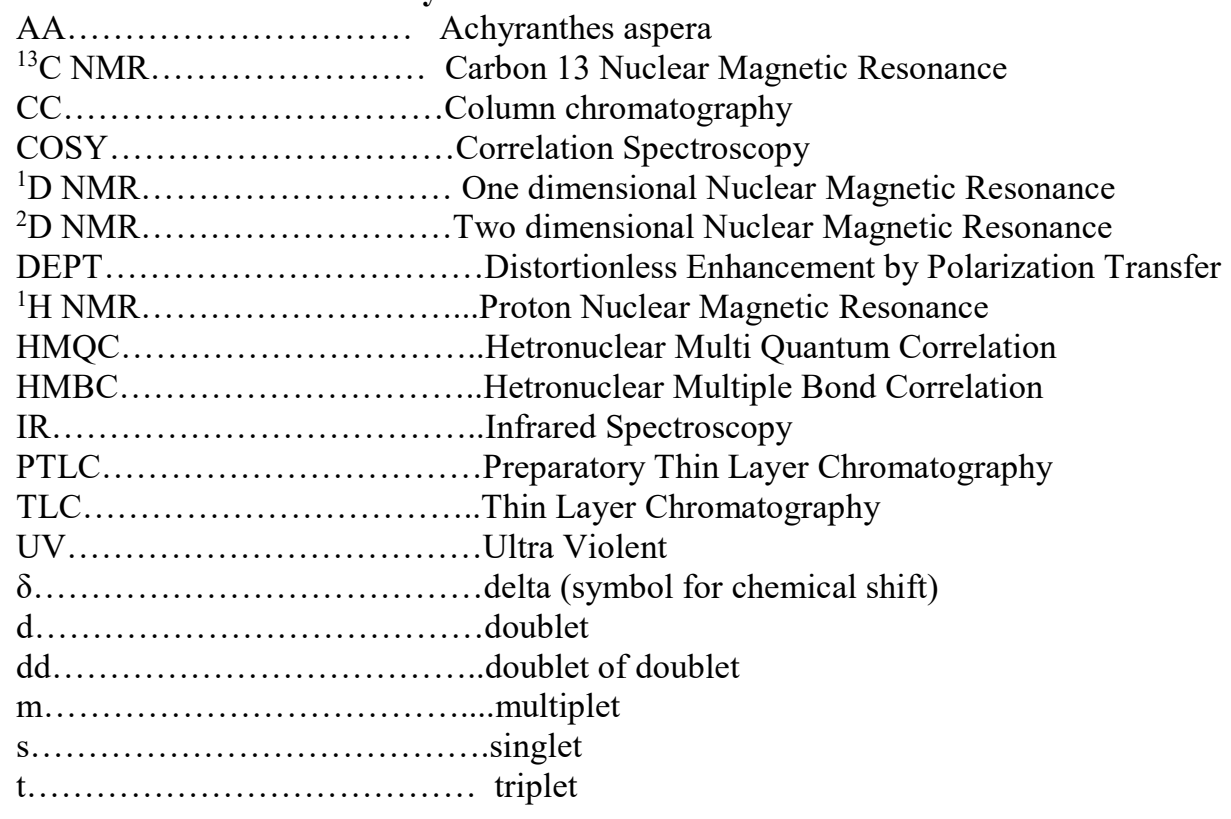

\section{Tables}

Table 1: ${ }^{1} \mathrm{H},{ }^{13} \mathrm{C}$ and DEPT NMR shifts of compound AA-1 (TMS, $\left.\mathrm{CD}_{3} \mathrm{OD}, 3^{0} \mathrm{C}\right)$

\begin{tabular}{llll}
\hline Position & \multicolumn{1}{c}{$\delta_{\mathrm{H}}$} & $\delta_{\mathrm{C}}$ & $\delta_{\mathrm{C}}(\mathrm{DEPT}-135)$ \\
\hline & & 73.2 & 73.2 \\
1 & $4.55(1 \mathrm{H}, \mathrm{t})$ & 49 & 49 \\
2 & $2.62(1 \mathrm{H}, \mathrm{d}) \& 2.19(1 \mathrm{H}, \mathrm{d})$ & 199.8 & - \\
3 & - & 125.7 & 125.7 \\
4 & $5.89(1 \mathrm{H}, \mathrm{s})$ & 165 & - \\
5 & - & 78 & - \\
6 & - & 22.0 & 22.0 \\
7 & $1.05(1 \mathrm{H}, \mathrm{m})$ & 132.30 & 132.30 \\
8 & $5.75(1 \mathrm{H}$, & 132.36 & 132.36 \\
9 & $6.01(1 \mathrm{H}, \mathrm{d})$ & 41 & - \\
10 & - & 23.3 & 23.3 \\
11 & $1.03(3 \mathrm{H}, \mathrm{s})$ & 18.0 & 18.0 \\
12 & $1.96(3 \mathrm{H}, \mathrm{s})$ & 20.6 & 20.6 \\
13 & $1.29(3 \mathrm{H}, \mathrm{d})$ & 99.8 & 99.8 \\
1 & $4.29(1 \mathrm{H}, \mathrm{d})$ & 76.8 & 76.8 \\
2 & $3.29(1 \mathrm{H}, \mathrm{m})$ & 73.5 & 73.5 \\
3 & $3.20(1 \mathrm{H}, \mathrm{m})$ & 70.2 & 70.2 \\
4 & $3.28(1 \mathrm{H}, \mathrm{m})$ & 76.9 & 76.9 \\
5 & $3.18(1 \mathrm{H}, \mathrm{m})$ & 61.4 & 61.4 \\
6
\end{tabular}


Table 2: COSY $(1 \mathrm{H} \leftrightarrow 1 \mathrm{H})$ correlation of $\mathbf{A A}-\mathbf{1}$

\begin{tabular}{|c|c|}
\hline Carbon No & $\operatorname{COSY}\left({ }^{1} \mathrm{H} \leftrightarrow{ }^{1} \mathrm{H}\right)$ \\
\hline C-9 $(\delta 132.36)$ & $\mathrm{H}-9 \leftrightarrow \mathrm{H}-8$ \\
\hline $\mathrm{C}-8(\delta 132.30)$ & $\mathrm{H}-8 \leftrightarrow \mathrm{H}-9$ \\
\hline $\mathrm{C}-4(\delta 125.7)$ & $\mathrm{H}-4 \leftrightarrow \mathrm{H}-12$ \\
\hline $\mathrm{C}-1^{\prime}(\delta 99.8)$ & H-1 ${ }^{\prime} \leftrightarrow \mathrm{H}-3^{\prime}$ \\
\hline$C-5^{\prime}(\delta 76.9)$ & H-5'↔H-6’ \\
\hline$C-2^{\prime}(\delta 76.8)$ & $\mathrm{H}-2^{\prime} \leftrightarrow \mathrm{H}-4^{\prime}$ \\
\hline$C-3^{\prime}(\delta 73.5)$ & H-3'↔H-1', \\
\hline $\mathrm{C}-1(\delta 73.2)$ & H-1↔H-13,H-9 \\
\hline $\mathrm{C}-4^{\prime}(\delta 70.2)$ & H-4'↔H-2' \\
\hline$C-6^{\prime}(\delta 61.4)$ & H-6’↔H-5',H-13 \\
\hline $\mathrm{C}-2(\delta 49.0)$ & $\mathrm{H}-2 \leftrightarrow \mathrm{H}-7, \mathrm{H}-11$ \\
\hline $\mathrm{C}-11(\delta 23.3)$ & H-11↔H-2,H-7 \\
\hline $\mathrm{C}-7(\delta 22.0)$ & $\mathrm{H}-7 \leftrightarrow \mathrm{H}-11$ \\
\hline $\mathrm{C}-13(\delta 20.6)$ & H-13↔H-1,H-6',H-12 \\
\hline $\mathrm{C}-12(\delta 18.0)$ & $\mathrm{H}-12 \leftrightarrow \mathrm{H}-4, \mathrm{H}-13$ \\
\hline
\end{tabular}

Table 3: HMQC correlation of AA-1

\begin{tabular}{|c|c|c|}
\hline Carbon No & Hydrogen No & Remark \\
\hline C-9 $(\delta 132.36)$ & $\delta 6.01(1 \mathrm{H}, \mathrm{d})$ & $\mathrm{CH}$ \\
\hline C-8 $(\delta 132.30)$ & $\delta 5.75(1 \mathrm{H}, \mathrm{dd})$ & $\mathrm{CH}$ \\
\hline C-4 $(\delta 125.7)$ & $\delta 5.89(1 \mathrm{H}, \mathrm{s})$ & $\mathrm{CH}$ \\
\hline $\mathrm{C}-1{ }^{\prime}(\delta 99.8)$ & $\delta 4.29(1 \mathrm{H}, \mathrm{d})$ & $\mathrm{CH}$ \\
\hline$C-5^{\prime}(\delta 76.9)$ & $\delta 3.18(1 \mathrm{H}, \mathrm{m})$ & $\mathrm{CH}$ \\
\hline $\mathrm{C}-2^{\prime}(\delta 76.8)$ & $\delta 3.29(1 \mathrm{H}, \mathrm{m})$ & $\mathrm{CH}$ \\
\hline$C-3,(\delta 73.5)$ & $\delta 3.20(1 \mathrm{H}, \mathrm{m})$ & $\mathrm{CH}$ \\
\hline C-1 $(\delta 73.2)$ & $\delta 4.55(1 \mathrm{H}, \mathrm{t})$ & $\mathrm{CH}$ \\
\hline $\mathrm{C}-4^{\prime}(\delta 70.2)$ & $\delta 3.28(1 \mathrm{H}, \mathrm{m})$ & $\mathrm{CH}$ \\
\hline$C-6^{\prime}(\delta 61.4)$ & $\delta 3.87(1 \mathrm{H}, \mathrm{d}) \& 3.65(1 \mathrm{H}, \mathrm{d})$ & $\mathrm{CH}_{2}$ \\
\hline $\mathrm{C}-2(\delta 49.0)$ & $\delta 2.62(2 \mathrm{H}, \mathrm{d}) \& 2.19(2 \mathrm{H}, \mathrm{d})$ & $\mathrm{CH}_{2}$ \\
\hline $\mathrm{C}-11(\delta 23.3)$ & $\delta 1.03(3 \mathrm{H}, \mathrm{s})$ & $\mathrm{CH}_{3}$ \\
\hline $\mathrm{C}-7(\delta 22.0)$ & $\delta 1.05(1 \mathrm{H}, \mathrm{m})$ & $\mathrm{CH}$ \\
\hline $\mathrm{C}-13(\delta 20.6)$ & $\delta 1.29(3 \mathrm{H}, \mathrm{d})$ & $\mathrm{CH}_{3}$ \\
\hline $\mathrm{C}-12(\delta$ 18.0 $)$ & $\delta 1.96(3 \mathrm{H}, \mathrm{s})$ & $\mathrm{CH}_{3}$ \\
\hline
\end{tabular}

Table 4: HMBC Correlation of AA-1.

\begin{tabular}{|c|c|}
\hline Proton No & Carbon's correlated \\
\hline H-9 & $\mathrm{H}-9 \leftrightarrow \mathrm{C}-1, \mathrm{C}-5, \mathrm{C}-6$ \\
\hline $\mathrm{H}-8$ & $\mathrm{H}-8 \leftrightarrow \mathrm{C}-1, \mathrm{C}-6, \mathrm{C}-13$ \\
\hline $\mathrm{H}-4$ & $\mathrm{H}-4 \leftrightarrow \mathrm{C}-2, \mathrm{C}-6, \mathrm{C}-12$ \\
\hline $\mathrm{H}-1$ & $\mathrm{H}-1^{\prime} \leftrightarrow \mathrm{C}-2^{\prime}, \mathrm{C}-5^{\prime}, \mathrm{C}-6$ \\
\hline $\mathrm{H}-5$ & $\mathrm{H}-5^{\prime} \leftrightarrow \mathrm{C}-6^{\prime}$ \\
\hline $\mathrm{H}-2$ & $\mathrm{H}-2^{\prime} \leftrightarrow \mathrm{C}-3^{\prime}$ \\
\hline H-3, & $\mathrm{H}-3^{\prime} \leftrightarrow \mathrm{C}-2^{\prime}, \mathrm{C}-4^{\prime}$ \\
\hline $\mathrm{H}-1$ & $\mathrm{H}-1 \leftrightarrow \mathrm{C}-9, \mathrm{C}-8, \mathrm{C}-13$ \\
\hline H-4' & $\mathrm{H}-4^{\prime} \leftrightarrow \mathrm{C}-3^{\prime}, \mathrm{C}-5^{\prime}$ \\
\hline H-6 & H-6’↔C-4',C-5', \\
\hline $\mathrm{H}-2$ & $\mathrm{H}-2 \leftrightarrow \mathrm{C}-3, \mathrm{C}-6, \mathrm{C}-4, \mathrm{C}-10$ \\
\hline $\mathrm{H}-11$ & $\mathrm{H}-11 \leftrightarrow \mathrm{C}-2, \mathrm{C}-3, \mathrm{C}-7, \mathrm{C}-10$ \\
\hline $\mathrm{H}-7$ & $\mathrm{H}-7 \leftrightarrow \mathrm{C}-6, \mathrm{C}-10, \mathrm{C}-11$ \\
\hline $\mathrm{H}-13$ & $\mathrm{H}-13 \leftrightarrow \mathrm{C}-1, \mathrm{C}-8$ \\
\hline $\mathrm{H}-12$ & $\mathrm{H}-12 \leftrightarrow \mathrm{C}-4, \mathrm{C}-5, \mathrm{C}-6$ \\
\hline
\end{tabular}


Table 5: ${ }^{1} \mathrm{H},{ }^{13} \mathrm{C}$ and DEPT NMR shifts of compound AA-2 (TMS, $\left.\mathrm{CD}_{3} \mathrm{OD}, 30^{\circ} \mathrm{C}\right)$

\begin{tabular}{llll}
\hline Position & \multicolumn{1}{c}{$\delta_{\mathrm{H}}$} & $\delta_{\mathrm{C}}$ & $\delta_{\mathrm{C}}(\mathrm{DEPT}-135)$ \\
\hline 1 & $1.83(1 \mathrm{H}, \mathrm{d}), 1.78(1 \mathrm{H}, \mathrm{m})$ & 37.4 & 37.4 \\
2 & $3.87(1 \mathrm{H}, \mathrm{m})$ & 68.7 & 68.7 \\
3 & $3.97(1 \mathrm{H}, \mathrm{m})$ & 68.5 & 68.5 \\
4 & $1.73(2 \mathrm{H}, \mathrm{m})$ & 30.8 & 30.8 \\
5 & $2.38(1 \mathrm{H}, \mathrm{m})$ & 51.8 & 51.8 \\
6 & - & 206.5 & - \\
7 & $5.83(1 \mathrm{H}, \mathrm{s})$ & 122.1 & 122.1 \\
8 & - & 168.0 & - \\
9 & $3.17(1 \mathrm{H}, \mathrm{t})$ & 35 & 35 \\
10 & - & 39.3 & - \\
11 & $1.79(1 \mathrm{H}, \mathrm{m}), 1.64(1 \mathrm{H}, \mathrm{m})$ & 21.5 & 21.5 \\
12 & $2.08(1 \mathrm{H}, \mathrm{m}), 1.82(1 \mathrm{H}, \mathrm{m})$ & 32.5 & 32.5 \\
13 & - & $49 *$ & - \\
14 & - & 85.2 & - \\
15 & $1.95(1 \mathrm{H}, \mathrm{m}), 1.62(1 \mathrm{H}, \mathrm{m})$ & 31.8 & 31.8 \\
16 & $1.99(2 \mathrm{H}, \mathrm{m})$ & 23.7 & 23.7 \\
17 & $2.41(1 \mathrm{H} \mathrm{t})$ & 50.5 & 50.5 \\
18 & $0.90(3 \mathrm{H}, \mathrm{s})$ & 18.0 & 18.0 \\
19 & $0.95(3 \mathrm{H}, \mathrm{s})$ & 24.4 & 24.4 \\
20 & - & 77.9 & - \\
21 & $1.30(3 \mathrm{H}, \mathrm{s})$ & 21.0 & 21.0 \\
22 & $3.32(1 \mathrm{H}, \mathrm{t})$ & 78.4 & 78.4 \\
23 & $1.59(2 \mathrm{H}, \mathrm{m})$ & 27.3 & 27.3 \\
24 & $1.72(1 \mathrm{H}, \mathrm{m}), 1.45(1 \mathrm{H}, \mathrm{m})$ & 42.4 & 42.4 \\
25 & - & 71.3 & - \\
26 & $1.22(3 \mathrm{H}, \mathrm{s})$ & 29.7 & 29.7 \\
27 & $1.21(3 \mathrm{H}, \mathrm{s})$ & 28.9 & 28.9 \\
\hline
\end{tabular}

The symbol * indicates the peak that observed at $\delta 49$ is overlapped by the solvent

Table 6: COSY Correlation of AA-2

\begin{tabular}{|c|c|}
\hline Carbon No & $\operatorname{COSY}\left({ }^{1} \mathrm{H} \leftrightarrow{ }^{1} \mathrm{H}\right)$ correlation \\
\hline $\mathrm{C}-7(\delta 122.1)$ & H-7↔H-9 \\
\hline $\mathrm{C}-22(\delta 78.4)$ & $\mathrm{H}-22 \leftrightarrow \mathrm{H}-21$ \\
\hline $\mathrm{C}-2(\delta 68.7)$ & $\mathrm{H}-2 \leftrightarrow \mathrm{H}-4, \mathrm{H}-3, \mathrm{H}-1$ \\
\hline $\mathrm{C}-3(\delta 68.5)$ & $\mathrm{H}-3 \leftrightarrow \mathrm{H}-2, \mathrm{H}-1$ \\
\hline $\mathrm{C}-17(\delta 50.5)$ & $\mathrm{H}-17 \leftrightarrow \mathrm{H}-15, \mathrm{H}-12$ \\
\hline $\mathrm{C}-1(\delta 37.4)$ & $\mathrm{H}-1 \leftrightarrow-3, \mathrm{H}-2$ \\
\hline $\mathrm{C}-9(\delta 35.1)$ & $\mathrm{H}-9 \leftrightarrow \mathrm{H}-7, \mathrm{H}-1$ \\
\hline $\mathrm{C}-12(\delta 32.5)$ & H-12↔H-17,H-11 \\
\hline $\mathrm{C}-15(\delta 31.8)$ & H-15↔H-17,H-16 \\
\hline $\mathrm{C}-4(\delta 30.8)$ & $\mathrm{H}-4 \leftrightarrow \mathrm{H}-2$ \\
\hline $\mathrm{C}-16(\delta 27.3)$ & $\mathrm{H}-16 \leftrightarrow \mathrm{H}-15$ \\
\hline $\mathrm{C}-11(\delta 21.5)$ & $\mathrm{H}-11 \leftrightarrow \mathrm{H}-12$ \\
\hline $\mathrm{C}-21(\delta 21)$ & $\mathrm{H}-21 \leftrightarrow \mathrm{H}-22, \mathrm{H}-18$ \\
\hline $\mathrm{C}-18(\delta 18)$ & $\mathrm{H}-18 \leftrightarrow \mathrm{H}-21$ \\
\hline
\end{tabular}


Table 7: HMQC Correlation of AA-2

\begin{tabular}{|c|c|c|}
\hline Carbon No & Hydrogen No & Remark \\
\hline $\mathrm{C}-7(\delta 122.1)$ & $5.83(1 \mathrm{H}, \mathrm{s})$ & $\mathrm{CH}$ \\
\hline $\mathrm{C}-22(\delta 78.4)$ & $3.32(1 \mathrm{H}, \mathrm{t})$ & $\mathrm{CH}$ \\
\hline $\mathrm{C}-2(\delta 68.7)$ & $3.87(1 \mathrm{H}, \mathrm{m})$ & $\mathrm{CH}$ \\
\hline $\mathrm{C}-3(\delta 68.5)$ & $3.97(1 \mathrm{H}, \mathrm{m})$ & $\mathrm{CH}$ \\
\hline $\mathrm{C}-5(\delta 51.8)$ & $2.38(1 \mathrm{H}, \mathrm{m})$ & $\mathrm{CH}$ \\
\hline $\mathrm{C}-17(\delta 50.1)$ & $2.41(1 \mathrm{H}, \mathrm{t})$ & $\mathrm{CH}$ \\
\hline $\mathrm{C}-24(\delta 42.4)$ & $1.72(1 \mathrm{H}, \mathrm{m}, 1.45(1 \mathrm{H}, \mathrm{m})$ & $\mathrm{CH}_{2}$ \\
\hline $\mathrm{C}-1(\delta 37.4)$ & $1.83(1 \mathrm{~d}), 1.78(1 \mathrm{H}, \mathrm{m})$ & $\mathrm{CH}_{2}$ \\
\hline $\mathrm{C}-9(\delta 35.1)$ & $3.17(1 \mathrm{H}, \mathrm{t})$ & $\mathrm{CH}$ \\
\hline $\mathrm{C}-12(\delta 32.5)$ & $2.08,1.82$ & $\mathrm{CH}_{2}$ \\
\hline $\mathrm{C}-15(\delta 31.8)$ & $1.95,1.62$ & $\mathrm{CH}_{2}$ \\
\hline $\mathrm{C}-4(\delta 30.8)$ & $1.73(2 \mathrm{H}, \mathrm{m})$ & $\mathrm{CH}_{2}$ \\
\hline $\mathrm{C}-26(\delta 29.7)$ & $1.22(3 \mathrm{H}, \mathrm{s})$ & $\mathrm{CH}_{3}$ \\
\hline $\mathrm{C}-27(\delta 28.9)$ & $1.21(3 \mathrm{H}, \mathrm{s})$ & $\mathrm{CH}_{3}$ \\
\hline $\mathrm{C}-16(\delta 27.3)$ & $1.99(2 \mathrm{H}, \mathrm{m})$ & $\mathrm{CH}_{2}$ \\
\hline $\mathrm{C}-19(\delta 24.4)$ & $0.95(3 \mathrm{H}, \mathrm{s})$ & $\mathrm{CH}_{3}$ \\
\hline $\mathrm{C}-23(\delta 23.7)$ & $1.59(2 \mathrm{H}, \mathrm{m})$ & $\mathrm{CH}_{2}$ \\
\hline C-11(21.5) & $1.79(1 \mathrm{H}, \mathrm{m}), 1.64(1 \mathrm{H}, \mathrm{m})$ & $\mathrm{CH}_{2}$ \\
\hline $\mathrm{C}-21(\delta 21)$ & $1.30(3 \mathrm{H}, \mathrm{s})$ & $\mathrm{CH}_{3}$ \\
\hline $\mathrm{C}-18(\delta 18)$ & $0.90(3 \mathrm{H}, \mathrm{s})$ & $\mathrm{CH}_{3}$ \\
\hline
\end{tabular}

Table 8: HMBC Correlation of AA-2.

\begin{tabular}{ll}
\hline Proton No & Carbons correlated \\
\hline H-27 & C-24,C-25,C-22 \\
H-19 & C-5,C-1 \\
H-18 & C-14,C-13,C-12 \\
\hline
\end{tabular}

\section{Figures}

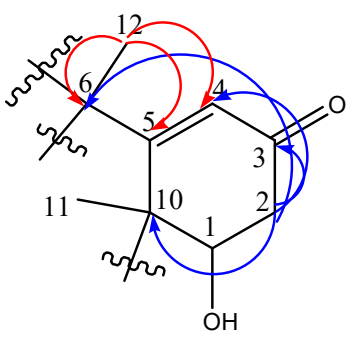

Figure 1: Partial structure I: HMBC Correlation of compound AA-1

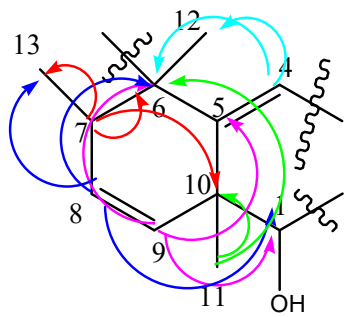

Figure 2: Partial structure II: HMBC correlation of AA-1 


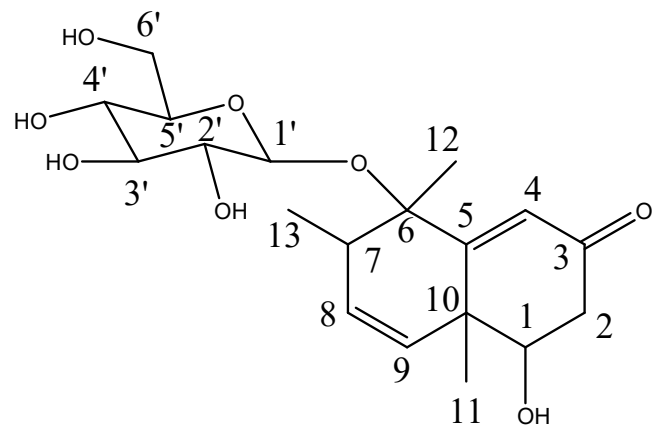

Figure 3: Structure of Compound AA-1

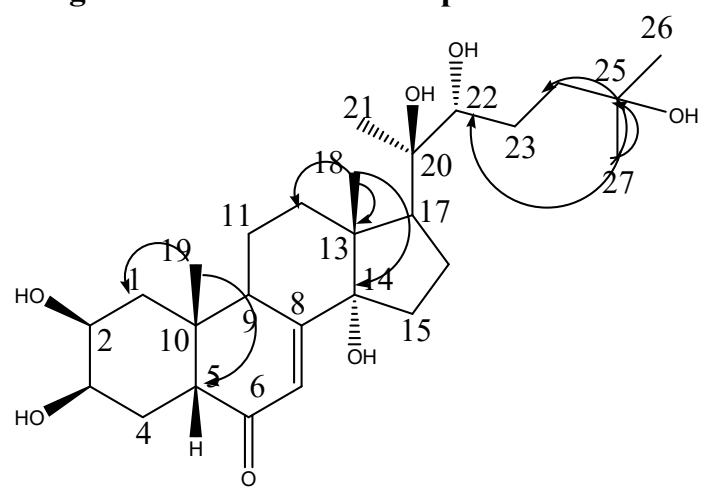

Figure 4: HMBC correlation of compound AA-2.

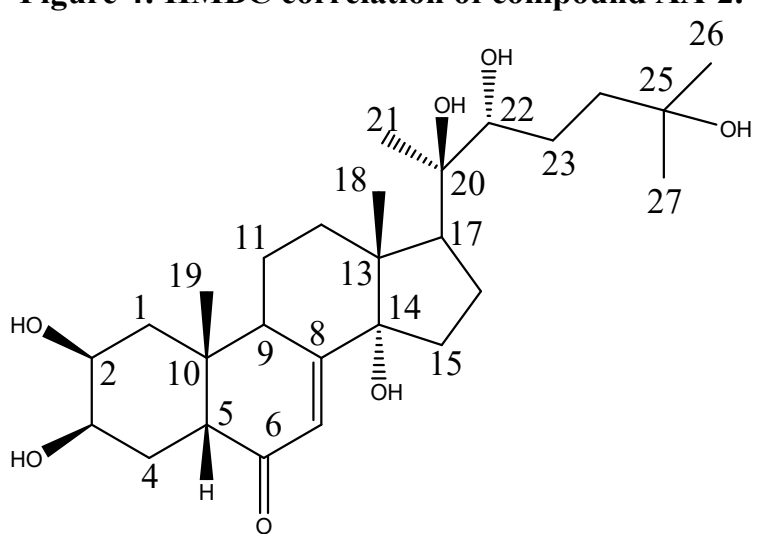

Figure 5: Structure of compound AA-2. 